\title{
Influence of Fine Supplementary Cementitious Materials on Compressive Strength of Concrete - a State of Art Review
}

\author{
Vaibhav Jain*, Gaurav Sancheti†, Bhupesh Jain \\ Department of Civil Engineering, Manipal University Jaipur, Dehmi Kalan, off Jaipur-Ajmer Expressway, \\ Jaipur, Rajasthan 303007, India
}

(Received 11 January 2021; revised manuscript received 24 March 2021; published online 09 April 2021)

\begin{abstract}
Concrete is one of the most utilized and preferred construction materials in almost all the regions of the world. It is mainly known for its compressive strength. Several megastructures such as bridges, spillways, high-rise buildings, dams, etc. require sufficient compressive strength to suitably bear the upcoming large load on them. At the same time, in recent years, a lot of industrial by-products that are dumped as an industrial waste have attracted attention on concrete technologists. To safeguard the land from becoming the dumping zone/landfill sites, several researchers have come up and utilized these wastes as a supplementary cementitious material (SCM) in concrete. These SCMs can be used either in addition or in replacement of cement. In this paper, the effect of varying particle size and proportion of SCMs on compressive strength of concrete has been reviewed. Efforts have been made to showcase the effective utilization of various industrial by-products in manufacture of concrete with comparable compressive strength.
\end{abstract}

Keywords: Nanomaterials, Compressive strength, Concrete, Supplementary cementitious material, Rice husk ash, Fly ash, Silica fume, Ground granulated blast furnace slag.

DOI: $10.21272 /$ jnep.13(2).02021

PACS numbers: $61.46 .+\mathrm{w}, 61.43 . \mathrm{Gt}$

\section{INTRODUCTION}

Most of the infrastructure development that consist of roads, buildings, water tanks etc. requires to be built up with materials having high compressive strength. As such, for their construction it requires a huge amount of concrete [1] that is one of the most preferred construction material. Cement along with aggregates and water in certain proportion is required to produce concrete [2]. Particularly concrete is known for its compressive strength and that is why it is used in developing infrastructure. There are certain guidelines laid down by Indian standard IS10262 for designing a particular grade of concrete with a minimum amount of cement. The production of this cement quantity leads to higher emissions of carbon dioxide that impacts the environment to a greater extent. Production of 1 ton of cement produces almost same amount of carbon dioxide that have a severe impact on the environment [3]. Around $7 \%$ of the global carbon dioxide emission is due to the production of cement. However, cement plays a vital role in the compressive strength of concrete as it helps in formation of $\mathrm{CSH}$ gel that is responsible for overall strength in concrete. So our main focus is to review some of the SCMs [4] that are partially replaced by cement without affecting the compressive strength of concrete. These by-products or SCMs obtained from the industries are considered as a waste and are generated in huge amount. This raises the problem of their disposal, as these industrial by products are not environmentally friendly. So, to mitigate this problem, several researchers have tried to utilize these waste industries generated by-products in concrete, either as a cement or aggregate replacement. In this study, a comprehensive state of art review is presented on the SCMs that are used in place of cement in concrete providing the acceptable level of compressive strength. Various SCMs considered are rice husk ash (RHA), silica fume (SF), fly ash (FA) and ground granulated blast furnace slag (GGBS).

The whole aim of this study is to support engineering community for different types of works that have been conducted on compressive strength of concrete with partial replacement of cement with industrial by products that are considered as wastes.

\subsection{Background of SCMs}

SCMs are the industrial waste generated because of processing or manufacturing of various products. They can be replaced either as a cement or aggregates. In the present study, replacement of cement with a particle size ranging from micro to nanoscale is considered. Comparison has been made between fine SCMs such as RHA, FA, SF and GGBS. The physical and chemical properties of these SCMs are shown in Table 1 and Table 2, respectively.

Table 1 - Physical properties of SCMs

\begin{tabular}{|c|l|c|c|c|c|}
\hline \multirow{2}{*}{$\begin{array}{c}\text { S. } \\
\text { No. }\end{array}$} & \multirow{2}{*}{ Properties } & \multicolumn{4}{|c|}{ SCMs } \\
\cline { 2 - 6 } & RHA [5] & SF [6] & GGBS [7] & FA [1] \\
\hline $\mathbf{1}$ & $\begin{array}{l}\text { Specific } \\
\text { gravity }\end{array}$ & 2.32 & 2.22 & 2.9 & 2.17 \\
\hline $\mathbf{2}$ & $\begin{array}{l}\text { Particle size } \\
(\mathrm{mm})\end{array}$ & 22.31 & $<1$ & 30 & - \\
\hline $\mathbf{3}$ & $\begin{array}{l}\text { Specific } \\
\text { surface area } \\
\left(\mathrm{m}^{2} / \mathrm{kg}\right)\end{array}$ & 292.11 & 18700 & $425-470$ & 263 \\
\hline
\end{tabular}

In the recent decades, several studies have been conducted on these particular SCMs and they have

\footnotetext{
*vaibhav.jain0492@gmail.com

$\dagger$ gaurav.sancheti@jaipur.manipal.edu

The results were presented at the International Conference on Multifunctional Nanomaterials (ICMN2020)
} 
shown a greater potential towards as a cement replacement material. Using them can highly control the emissions of carbon dioxide that is liberated during the production of cement.

Table 2 - Chemical properties of SCMs

\begin{tabular}{|c|c|c|c|c|c|}
\hline \multirow{2}{*}{$\begin{array}{l}\text { S. } \\
\text { No. }\end{array}$} & \multirow{2}{*}{$\begin{array}{c}\text { Oxides } \\
(\%)\end{array}$} & \multicolumn{4}{|c|}{ SCMs } \\
\hline & & RHA [5] & SF [6] & GGBS [8] & FA [1] \\
\hline 1 & $\mathrm{SiO}_{2}$ & 91.45 & 92.60 & 35.34 & 58.33 \\
\hline 2 & $\mathrm{Fe}_{2} \mathrm{O}_{3}$ & 0.18 & 0.48 & 0.35 & 3.49 \\
\hline 3 & $\mathrm{CaO}$ & 0.99 & 0.34 & 41.99 & 5.72 \\
\hline 4 & $\mathrm{Al}_{2} \mathrm{O}_{3}$ & 0.44 & 0.82 & 11.59 & 26.23 \\
\hline 5 & $\mathrm{MgO}$ & 0.36 & 1.44 & 8.04 & 1.26 \\
\hline 6 & $\mathrm{SO}_{3}$ & 0.04 & 0.47 & 0.23 & - \\
\hline 7 & $\mathrm{Na}_{2} \mathrm{O}$ & 0.11 & 0.40 & - & 0.27 \\
\hline 8 & $\mathrm{~K}_{2} \mathrm{O}$ & 1.39 & 1.22 & - & 0.48 \\
\hline 12 & LoI & 1.39 & - & - & 2.76 \\
\hline
\end{tabular}

\section{SCMS USED AS A PARTIAL REPLACEMENT OF CEMENT}

\subsection{Rice Husk Ash (RHA)}

Rice husk ash (RHA) is obtained from paddy fields and is a byproduct from rice milling in rice producing countries. When rice husk is burned at a temperature below $700{ }^{\circ} \mathrm{C}$ it gives rise to ash termed as RHA that contains reactive amorphous silica [9, 10].

In Fig. 1, SEM images of cement and RHA is shown which depicts that RHA particles have smooth surface as compare to that of OPC particle. RHA particles are highly porous and have higher water absorption capacity that increases the demand of super plasticizer [5].

Natt Makul (2019) [5] investigated the high performance self-consolidating concrete. Untreated RHA and foundry sand waste (FDW) with a varying proportion of both the material were used in concrete. Water binder ratio of 0.35 and 0.45 was taken. The RHA used was replaced with cement in the amounts of 10 and $20 \%$ by weight of cement, along with foundry sand in the proportion of 30 and $50 \%$ by weight of sand. The optimum result was obtained at $10 \%$ replacement of RHA with $30 \%$ replacement of FDW that indicated the highest compressive strength. The result obtained at $10 \%$ replacement was higher because of pozzolanic reaction of RHA along with FDW having a greater filling effect and densified the capillary pores within the RHA enhances the compressive strength.

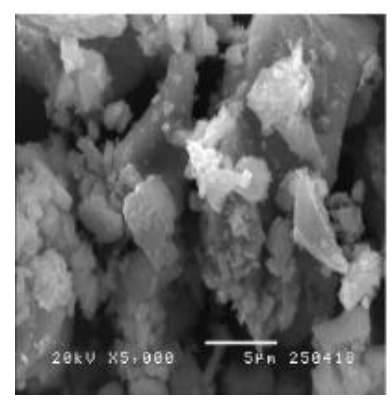

a

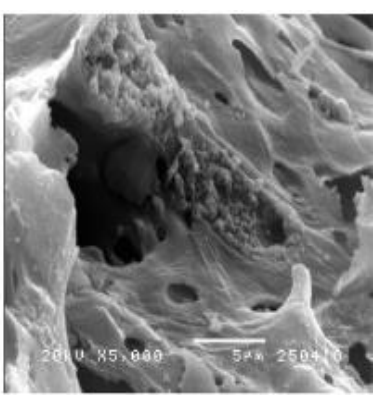

$\mathrm{b}$
Fig. 1 - SEM micrographs: (a) cement; b) RHA [5]
Mahdi Koushkbaghi et al. (2019) [11] studied the compressive strength of the concrete mix prepared with $20 \%$ RHA with replacement of cement. The strength obtained was higher due to $\mathrm{Si}-\mathrm{O}-\mathrm{Si}$ bonds due to the presence of excessive silica in RHA. RHA is a fine material due to which it densifies the matrix, reducing the porosity that is responsible for increase in strength of concrete. The strength at later ages is higher due to the release of the trapped water into the pores that enhance the hydration. Thus, higher $\mathrm{C}-\mathrm{S}-\mathrm{H}$ gel formation and dense microstructure is achieved.

\subsection{Fly Ash (FA)}

Fly Ash (FA) is a waste material obtained from the combustion of coal and used as a partial replacement of cement in the production of concrete. The global production of FA is around 800 million tons and most of the generated amount is dumped into the landfills which raises the problem after some time [1]. It mainly consists of silicates, glass and silica, alumina, iron etc., $[12,13]$. It is specifically classified as Class C and Class $\mathrm{F}$ as per ASTM standards. Basically the difference between them is of chemical composition of ash. Class $\mathrm{F}$ FA contains more pozzolanic compounds around $70 \%$ and that of class C FA contains $50-70 \%$ of pozzolanic compound.

Various findings had revealed that the compressive strength value at initial days of curing is lower due to the non-reactivity of FA. As the time progresses the strength improves. Fig. 2 depicts the compressive strength of concrete by various authors having different proportion of FA as 40, 50 and 60 w. \% of cement [14]. It can be summarized from Fig. 2 that optimum amount of FA can be in the range of $40-50 \mathrm{w}$. \% of cement.

Sudha Uthaman et al. (2018) [15] studied the strength and durability properties of concrete in seawater environment. Different mixes were prepared and the concrete properties were determined at various interval of time with different curing conditions. Concrete was casted with FA proportion of 40 w. \% of cement and OPC proportion was $60 \mathrm{w} \%$. Also $2 \%$ of OPC was replaced with nanotitania and nanocalcium carbonate [16]. The early strength was observed due to the accelerating effect of nanocalcium carbonate.

\subsection{Silica Fume (SF)}

Silica Fume (SF) is a byproduct obtained from the silicon and Ferro silicon industry $[6,17]$. The high purity quartz reduces to silicon at a temperature about $2000{ }^{\circ} \mathrm{C}$ produces silicon dioxide vapors. Majorly particle size of SF is less than $1 \mu \mathrm{m}$. And it contains very large amount of amorphous silica dioxide [18] and having very fine spherical particle. Due to its amorphous nature and fineness its reactivity is very high.

When SF is added to the concrete it produces very good results because it improves the aggregate paste bond of the mix [6]. In plain concrete aggregate works as an inert filler which creates the weak interfacial zone, due to which the concrete produced is weaker then cement paste. But by the addition of SF it eliminates this weak link and produce a higher strength concrete. 


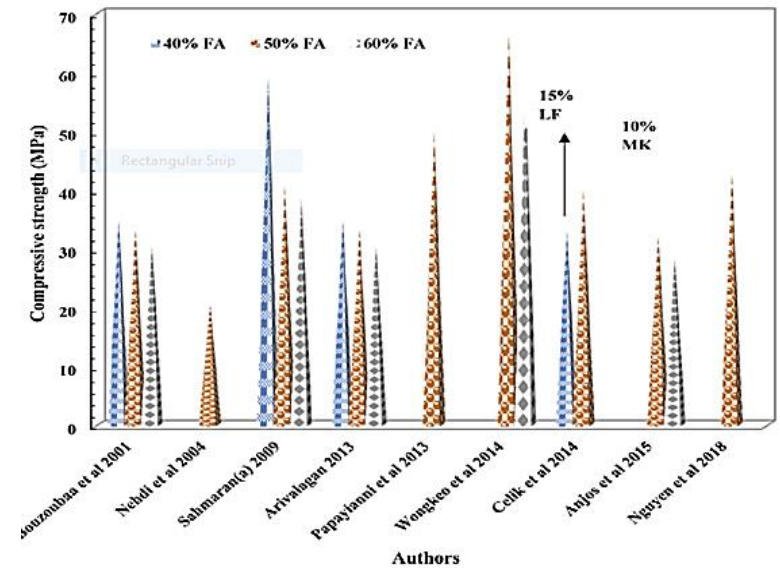

Fig. 2 - Compressive strength of concrete with various ratio of FA [1]

Wong et al. (2005) [19] studied the compressive strength of concrete produced with SF at different water cement ratio presented in Table 3 . It was observed that initially the strength was lower may be due to dilution effect of the pozzolana. Liu et al. (2020) [20] studied the various properties of concrete by including steel fiber and SF in a certain proportion and found out that the inclusion of $30 \%$ of SF gives the best results for the compressive strength.

Table 3 - Compressive strength of concrete with different ratio of SF [19]

\begin{tabular}{|c|c|c|c|}
\hline Mixture & \multicolumn{3}{|c|}{ Compressive strength (MPa) } \\
\hline & 28 days & 56 days & 90 days \\
\hline W/C 0.27 & 84 & 86.5 & 87.5 \\
\hline SF 5 & 88.5 & 93 & 96.5 \\
\hline SF 10 & 95.5 & 100 & 104 \\
\hline SF 15 & 101 & 103.5 & 106 \\
\hline
\end{tabular}

\subsection{Ground Granulated Blast Furnace Slag (GGBS)}

GGBS is a byproduct obtained from the blast furnaces used to make iron [7]. Replacement rate of GGBS is from $30-85 \%$. Fig. 3 shows the XRD diagram of paste containing $40 \%$ of GGBS as a replacement of cement. The figure indicates the pozzolanic activity of GGBS indirectly.

Wan et al.(2004) [21] studied the effect of compressive strength and activity index in mortar and revealed that mortar strength is related to size of particle and surface area. As the mortar contained more fine particle similar to that of size of GGBS, it provides better results and early strength was higher. The mortar prepared with $3-20 \mu \mathrm{m}$ particle size of GGBS it provides higher long term strength.

Cakir et al. (2008) [22] studied the compressive strength of mortar with different curing condition with and without the addition of GGBS. GGBS was used in the proportion of 0,30 and $60 \%$ by weight of cement. As the different curing condition, one batch of sample cured in water at $20^{\circ} \mathrm{C}$ and the other batch was cured in moisture cabinet at $40{ }^{\circ} \mathrm{C}$. Results revealed that compressive strength of concrete increases under both the curing condition as compare to that of normal mortar with no amount of GGBS.

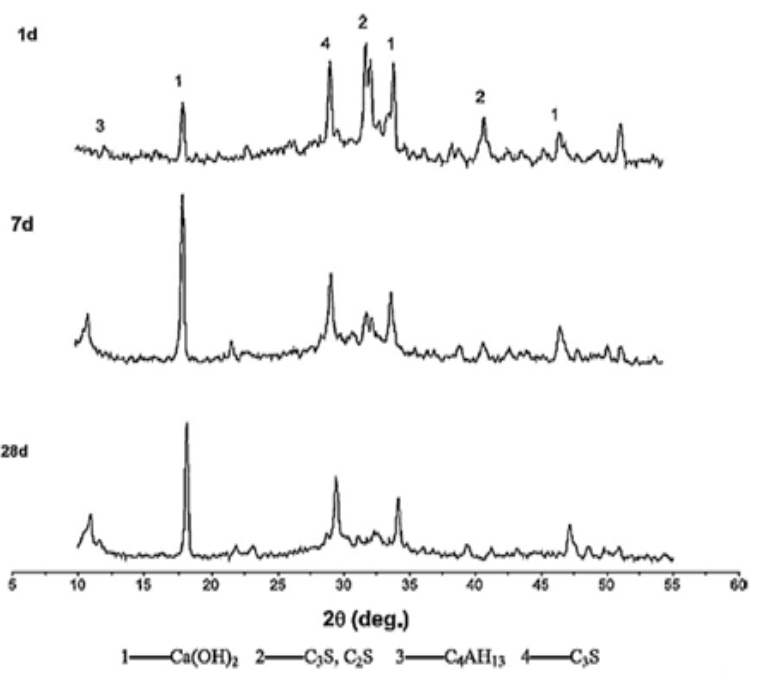

Fig. 3 - XRD diagram of paste with $40 \%$ GGBS replacing $40 \%$ of Portland cement [7]

\section{DISCUSSION AND CONCLUSIONS}

Addition of SCMs having a significant effect on compressive strength of concrete. Fig. 4 shows the effect of different proportions of various SCMs on the compressive strength of concrete.

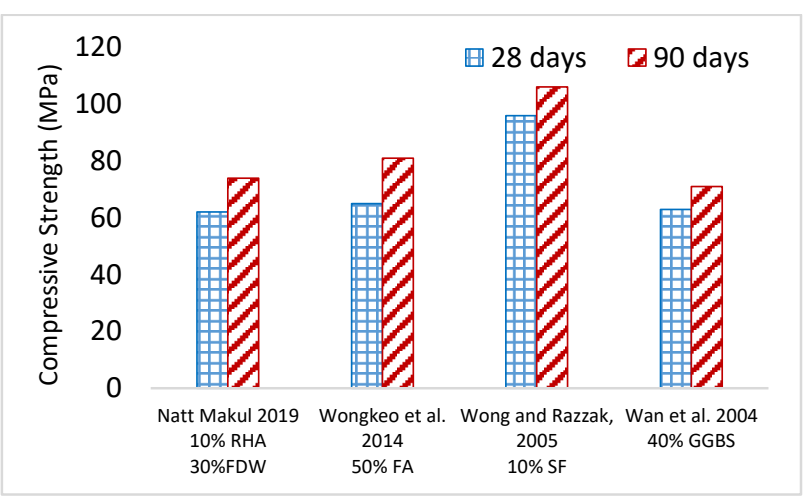

Fig. 4 - Compressive strength of various SCMs

- It was observed that addition of RHA at $30 \%$ replacement level shows the optimum result for the strength.

- As per various researcher optimum dosage of FA, SF and GGBS are $40 \%, 10-15 \%$, and $30 \%$, respectively by weight of cement.

- Strength is increases basically due to the particle size of this material which are added as a partial replacement of cement forming a very dense concrete. Due to which the packing of all the materials in concrete or mortars is very good. Hence, the strength also increases.

- As the materials which are used in place of cement having fine particle size due to which it requires higher amount of water and also the demand of super plasticizers increases. 
- By the addition of these micromaterials in concrete replacing partially with cement having good impact on the compressive strength of concrete.

- As the technology improved, it provides lot of information about the material. Many researchers study the effect of SCM in various proportion.

\section{ACKNOWLEDGEMENTS}

This paper is a part of the seed grant supported from Manipal University Jaipur. Authors greatly acknowledge the support of all faculty and laboratory staff for carrying out this work.

\title{
REFERENCES
}

1. N. Singh, P. Kumar, P. Goyal, J. Build. Engg. 26, 100882 (2019).

2. A.S. Gill, R. Siddique, Constr. Build. Mater. 176, 323 (2018).

3. A.L.G. Gastaldini, M.P. Silva, F.B. Zamberlan, C.Z.M. Neto, Constr. Build. Mater. 54, 369 (2014).

4. Y. Labbaci, Y. Abdelaziz, A. Mekkaoui, A. Alouani, B. Labbaci, Constr. Build. Mater. 133, 468 (2017).

5. N. Makul, Results in Materials,1 (2019).

6. R. Siddique, Resources, Conserv. Recycl. 55, 923 (2011).

7. R. Siddique, R. Bennacer, Resources, Conserv. Recycl. 69, 29 (2012).

8. W.A. Tasong, S. Wild, R.J.D. Tilley, Cement Conc. Res. 29, 975 (1999).

9. P. Chindaprasirt, Constr. Build. Mater. 21, 1356 (2007).

10. A.S. Gill, R. Siddique, Constr. Build. Mater. 157, 51 (2017).

11. M. Koushkbaghi, M. Jafar, H. Mosavi, E. Mohseni, Constr. Build. Mater. 202, 266 (2019).

12. A. Bicer, Therm. Sci. Eng. Prog. 8, 78 (2018).

13. L.N. Assi, E. Eddie, P. Ziehl, Constr. Build. Mater. 167, 372 (2018).

14. W. Wongkeo, P. Thongsanitgarn, A. Ngamjarurojana, A. Chaipanich, Mater. Design 64, 261 (2014).

15. S. Uthaman, V. Vishwakarma, R.P. George, D. Ramachandran, K. Kumari, R. Preetha, M. Premila, R. Rajaraman, U.K. Mudali, G. Amarendra, Constr. Build. Mater. 187, 448 (2018).

16. K. Kumari, R. Preetha, D. Ramachandran, V. Vishwakarma, Mater. Today Proc. 3, 2387 (2016).

17. D. Shen, J. Kang, Y. Jiao, M. Li, C. Li, Constr. Build. Mater. 263, 120218 (2020).

18. G. Adil, J.T. Kevern, D. Mann, Constr. Build. Mater. 247 , 118453 (2020).

19. H.S. Wong, H.A. Razak, Cement Conc. Res. 35, 696 (2005).

20. Y. Liu, C. Shi, Z. Zhang, N. Li, D. Shi, Cement Concr. Compos. 112, 103665 (2020).

21. H. Wan, Z. Shui, Z. Lin, Cem. Concr. Res. 34, 133 (2004).

22. Ö. Çakir, F. Aköz, Constr. Build. Mater. 22, 308 (2008).

\section{Вплив додаткових дрібних цементуючих матеріалів на міцність бетону на стиск - огляд сучасного стану}

\author{
Vaibhav Jain, Gaurav Sancheti, Bhupesh Jain \\ Department of Civil Engineering, Manipal University Jaipur, Dehmi Kalan, off Jaipur-Ajmer Expressway, \\ Jaipur, Rajasthan 303007, India
}

\begin{abstract}
Бетон е одним з найбільш використовуваних та улюблених будівельних матеріалів майже у всіх регіонах світу. В основному він відомий своею міцністю на стиск. Деякі мегаструктури, такі як мости, водозливи, висотні будинки, дамби тощо, вимагають достатньої міцності на стиск, щоб належним чином нести на собі майбутне велике навантаження. У той же час в останні роки велика кількість промислових побічних продуктів, які скидаються як промислові відходи, привертають увагу технологів 3 бетону. Щоб захистити землю від продуктів скидання та звалищ, ці відходи були підібрані і використані як додатковий цементуючий матеріал (SCM) у бетоні. Цей SCM може бути використаний як додатково, так і замінюючи цемент. У роботі розглянуто вплив різного розміру частинок та частки SCM на міцність бетону на стиск. Були докладені зусилля, щоб продемонструвати ефективне використання різних промислових побічних продуктів у виробництві бетону з достатньою міцністю на стиск.
\end{abstract}

Ключові слова: Наноматеріали, Міцність на стиск, Бетон, Додатковий цементуючий матеріал, Попіл рисового лушпиння, Зола, Кремнезем, Мелений гранульований доменний шлак. 